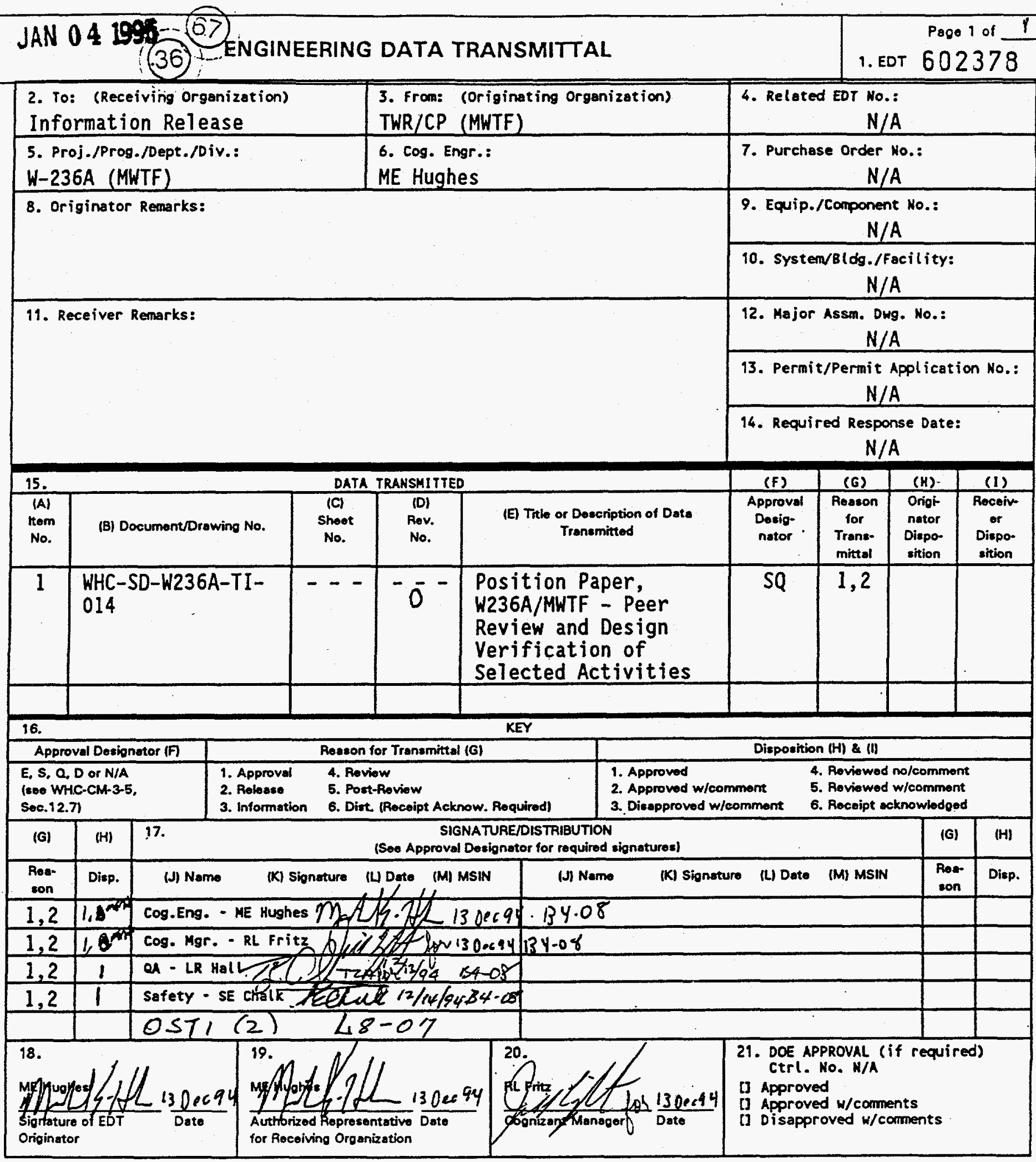

BD-7400-172-2 (04/94) GEFO97 


\section{DISCLAIMER}

Portions of this document may be illegible in electronic image products. Images are produced from the best available original document. 


\section{RELEASE AUTHORIZATION}

Document

Number:
WHC-SD-W236A-TI-014 Rev. 0

Position Paper - Peer Review and Design Verification of Selected Activities
Document

Title:
Release Date: January 4, 1995

\section{This document was reviewed following the procedures described in WHC-CM-3-4 and is:}

\section{APPROVED FOR PUBLIC RELEASE}

\section{WHC Information Release Administration Specialist:}

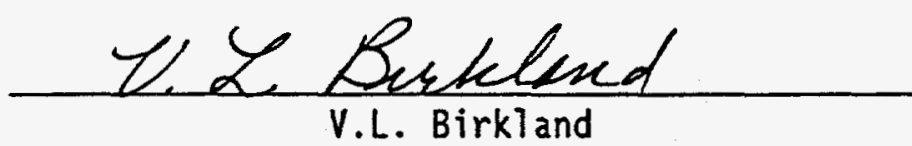

January 4,1995

TRADEMARK DISCLAIMER. Reference herein to any specific cormercial product, process, or service by trade name, trademark, manufacturer, or otherwise, does not necessarily constitute or imply its endorsenent, recomendation, or favoring by the United States Goverment or any agency thereof or its contractors or subcontractors.

This report has been reproduced from the best available copy. Available in paper copy and microfiche. Printed in the United States of America. Available to the U.S. Department of Energy and its contractors from:

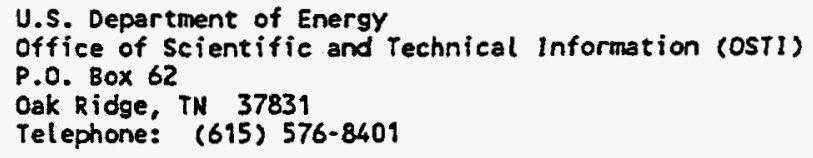


Position Paper - Peer Review and Design Verification of Selected Activities

\section{Key Words}

TANKS, MWTF, POSITION PAPER, PEER REVIEWS

\begin{tabular}{l|c} 
3. Number & $\begin{array}{c}\text { 4. Rev No. } \\
\text { WHC-SD-W236A-TI-014 }\end{array}$ \\
\hline
\end{tabular}

6. Author

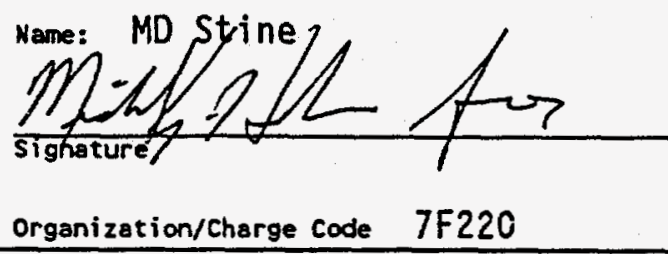

7. Abstract

Position Paper to develop and document a position on the performance of independent peer reviews on selected design and analysis components of the Title I (preliminary) and Title II (detailed) design phases of the Multi-Function Waste Tank Facility project.

\section{DISCLAIMER}

This report was prepared as an account of work sponsored by an agency of the United States Government. Neither the United States Government nor any agency thereof, nor any of their employees, makes any warranty, express or implied, or assumes any legal liability or responsibility for the accuracy, completeness, or usefulness of any information, apparatus, product, or process disclosed, or represents that its use would not infringe privately owned rights. Reference herein to any specific commercial product, process, or service by trade name, trademark, manufacturer, or otherwise does not necessarily constitute or imply its endorsement, recommendation, or favoring by the United States Government or any agency thereof. The views and opinions of authors expressed herein do not necessarily state or reflect those of the United States Government or any agency thereof.
8. RELEASE STAMP

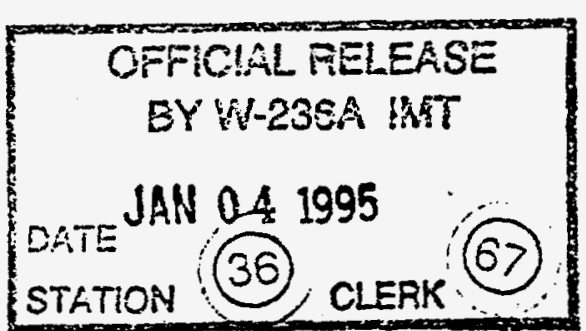




\title{
Position Paper Peer Review and Design Verification of Selected Activities
}

\author{
Multi-Function Waste Tank Facility \\ Project W-236A
}

prepared by ICF Kaiser Hanford Company
for Westinghouse Hanford Company

\section{September 1994}

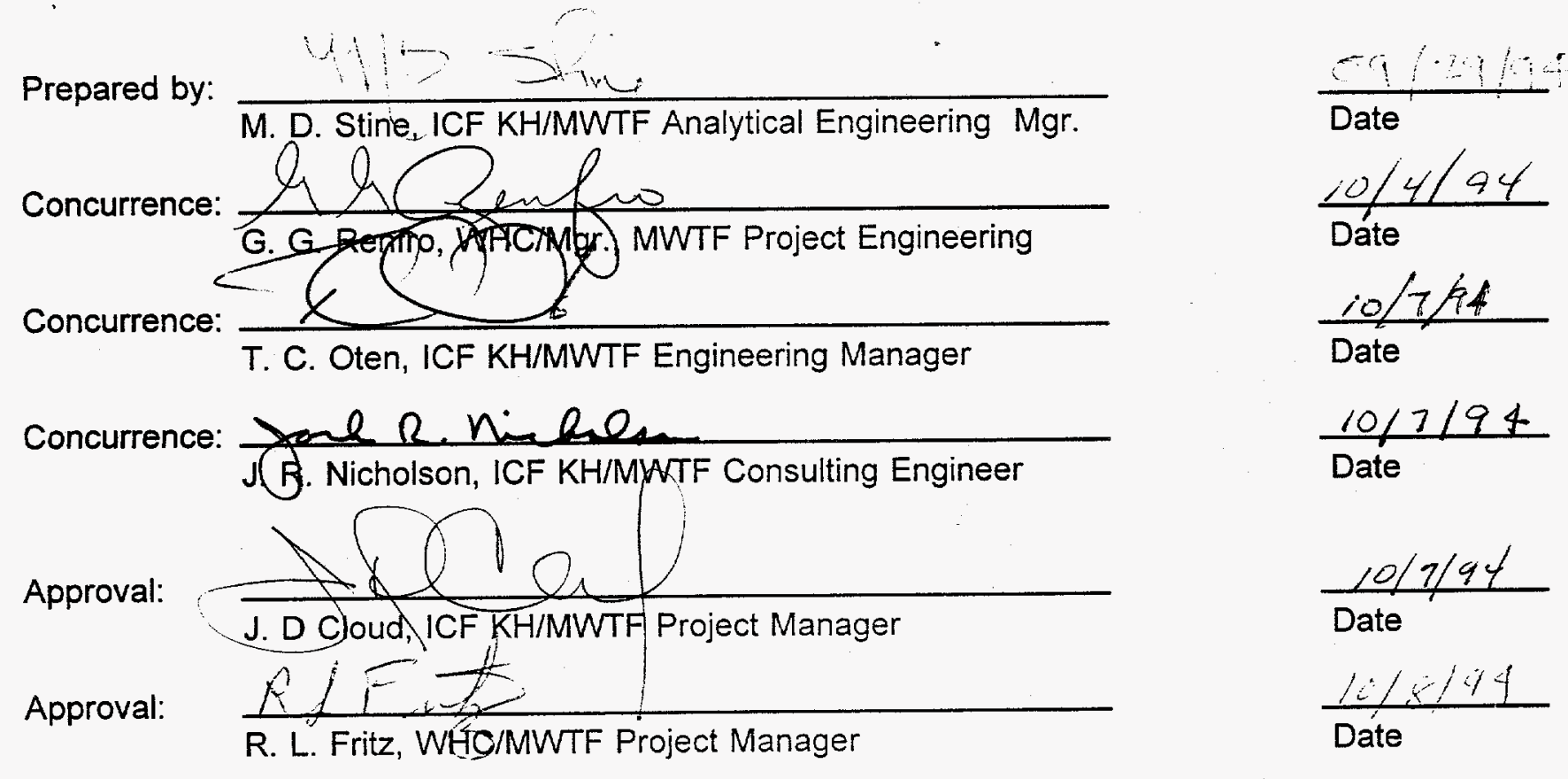


WHC-SD-W236A-TI-014

Rev. 0

W2364T2PP42

\section{Contents}

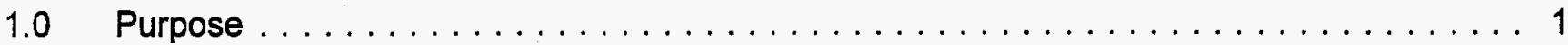

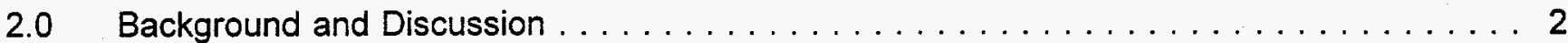

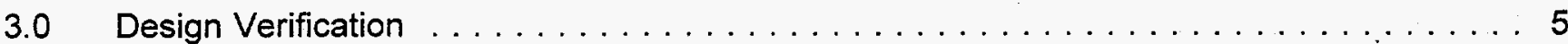

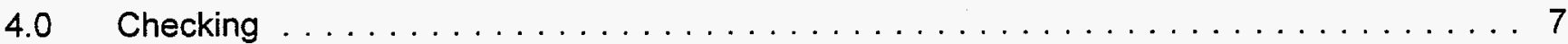

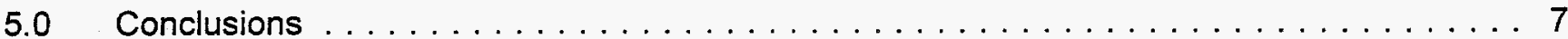

6.0 Recommendations $\ldots \ldots \ldots \ldots \ldots \ldots \ldots \ldots \ldots \ldots \ldots \ldots \ldots$

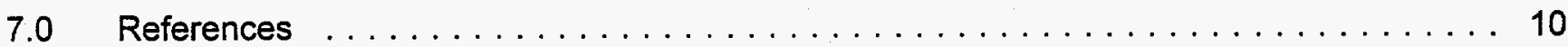




\section{Position Paper \\ Peer Review and Design Verification \\ of Selected Activities \\ Multi-Function Waste Tank Facility \\ Project W-236A}

\subsection{Purpose}

The purpose of this position paper is to develop and document a position on the performance of independent peer reviews on selected design and analysis components of the Title I (preliminary) and Title II (detailed) design phases of the Multi-Function Waste Tank Facility (MWTF) project.

An independent, third-party peer review is defined as a documented critical review of documents, data, designs, design inputs, tests, calculations, or related materials. A peer review must be conducted by persons independent of those who performed the work, but who are technically qualified to perform the original work. The peer review is used to accomplish the following:

- $\quad$ Assess the validity of assumptions and functional requirements.

- Assess the appropriateness and logic of selected methodologies and design inputs.

- Verify calculations, analyses, and the applicability of computer software.

The peer review can be conducted at the end of the design activity, at specific stages of the design process, or continuously and concurrently with the design activity. This latter method is often referred to as a "Continuous Peer Review". This peer review position paper supersedes the previous ICF Kaiser Hanford (ICF KH) internal peer review position paper prepared in February of 1994 (ref 1). 


\subsection{Background and Discussion}

Paragraph 0111-2.7.1 of Department of Energy (DOE) Order 6430.1A (ref 2) requires the following:

"An independent review of the seismic design shall be made for facilities and buildings where a seismic event can have a potential risk to operator lives, to public safety, or of large economic loss. The review shall be made in two stages, the first at the end of preliminary design and the second before final design is complete".

The above paragraph out of 6430.1A references LBL-9143 (ref 3) and UCRL 15910 (ref 4) for additional guidance on "independent review."

In addition, paragraph $0111-99.0 .4$ of DOE Order 6430.1A provides guidance for independent reviews for the seismic design of "special facilities" (defined as nonreactor nuclear facilities). This paragraph states the following:

"New seismic design, including additions or modifications to existing facilities, shall be reviewed by a qualified, independent organization. This review must include evaluation of the design approach, the lateral force resisting system, and the design detailing, per UCRL-15910. TM-5-809-10 (ref 5) can be used for design detail guidance."

In the foreword to Chapter 5 of LBL-9143, the author states that a "third-party review" or "independent review" of seismic designs is important in providing the OperatorManager of the facility (as well as the designer) with technical protection against gross errors, omissions, lack of experience, and other problems which may occur when sophisticated analysis obscures an understanding of the overall physical process. This document further states: 
"Frequently, the third party review will raise technical differences of opinion and questions of code interpretation or application. The resolution of such issues is, of course, vital to the performance of the structure".

UCRL 15910, paragraph 2.4 clearly shows that the term "independent review" is synonymous with the term "peer review." Paragraph 2.4 indicates that independent peer reviews must be included on all aspects of the design or evaluations of important or hazardous facilities. In addition, UCRL 15910 states that it may be prudent to perform concurrent independent evaluations of major hazardous facilities. UCRL 15910 is invoked by DOE 6430-1A (section 0111-99.0.4).

In addition, DOE Standard, DOE-STD-1020-94 (ref 6), which will replace UCRL 15910, states that for "Performance categories 2, 3, and 4 (roughly corresponding to Safety Class 3,2 , and 1, respectively), NPH design or evaluation must include independent peer review". Also, DOE-STD-1020 continues by stating that the peer reviewer, if from the same company as the designer/evaluator, "must not be part of the same program where he could be influenced by cost and schedule considerations," and "individuals performing peer reviews must be degreed civil/mechanical engineers with five or more years of experience in NPH evaluation."

Both UCRL 15910 and Draft DOE-STD-1020 refer to the ASCE Manual and Report on Engineering Practice No. 73 (ref 7) for additional guidance concerning the implementation of a formal peer review. Chapter 21 of this manual provides definitions, features, benefits, elements, scope, and reporting requirements for a formal peer review program. Manual No. 73 also states that:

"A Peer review is a review of an organization or project, conducted by peers of the original owner(s), manager(s), author(s), design professional(s), or constructor(s) who are independent of the subject of the review. A peer is defined as a person or group of persons with the same or higher level of 
technical or managerial expertise as those who are responsible for the subject of the review. Reviewers are generally from a separate organization, to eliminate relationships that would interfere with the impartiality of the review. If the reviewers are from within the same organization that is responsible for the office or project being reviewed, as occurs with some large organizations that have formal internal peer review programs, the reviewers should be sufficiently remote geographically and administratively so that there is no question of their independence and objectivity."

Further guidance may be found in NQA-3 (ref 8 ), where it states that:

"A documented critical review of work that goes beyond the state-of-the-art or where potential uncertainty exists, peer reviews are performed by one or more individuals who collectively have technical expertise at least equivalent to those who performed the original work. A peer review is an in-depth critique of assumptions, documents, calculations, extrapolations, alternate interpretations, methodology, acceptance criteria, conclusions, and material or data that require interpretation or judgement to verify or validate them."

On past projects, designs and analyses which have been performed on Safety Class 1 or 2 facilities and which involve complex or state-of-the-art techniques have had independent peer reviews performed by either in-house WHC personnel or by off-site analytical consultants with expertise in the analysis techniques used.

A good example of a formal peer review process can be found in the Basalt Waste Isolation Project (BWIP) Project Procedure for Peer Review (ref 9). This document states that a peer review is as "a documented critical technical review performed by personnel who are independent of those who performed the work and who are technically capable of performing the original work." The BWIP procedure also notes: 
"Peer reviews are required to qualify:

- Procedures for test and/or analysis which employ untried or beyond state-of-the-art techniques.

- Procedures for and the results from analytical modeling which will be applied outside normally accepted boundaries.

- $\quad$ Procedures for activities not feasibly repeatabie.

- Design input where interpretation or judgment is the principal method of confirming the adequacy.

- Design input in the absence of technical criteria and requirements to provide confidence in the data collection results."

\subsection{Design Verification}

ICF Kaiser Hanford (ICF KH) Quality Management Program, the MWTF Quality Assurance Program Plan (QAPP) (ref 10), ASME NQA-1 - Supplement 3S-1 (ref 11), DOE Order 6430.1A (Section 0140), WHC Procedure WHC-CM-6-1, EP-4.1 (ref 12), and ICF KH procedure ES-7 (ref 13) require that formal design verification be performed on designs for all safety class structures, systems, or components:

- WHC Procedure WHC-CM-6-1, EP-4.1 states that the objective of design verification

"... is to ensure that a design is technically adequate; that design inputs have been evaluated and verified for their impact on the design; and that the design meets applicable requirements for quality, safety, and performance at a reasonable cost."

- $\quad$ ICF KH Procedure ES-7 defines Design Verification as "Design control measures, such as design reviews, alternate calculations, or qualification tests, which are performed to verify the adequacy of design." Design verification is to be accomplished by qualified personnel other than those who performed the 
original design. This procedure specifically applies to all projects and work assignments designated as Safety Class 1.

- $\quad$ The MWTF QAPP requires that "safety class designs shall be verified in accordance with A/E-written instructions and procedures by independent qualified personnel."

- Similarly, NQA-1 states,

"Design control measures shall be applied to verify the adequacy of design, such as by one or more of the following: the performance of design reviews, the use of alternate calculations, or the performance of qualification tests. Design verification shall be performed by any competent individual(s) or group(s) other than those who performed the original design but who may be from the same organization. This verification may be performed by the originator's supervisor, provided the supervisor did not specify a singular design approach or rule out certain design considerations and did not establish the design inputs used in the design or, provided the supervisor is the only individual in the organization competent to perform the verification."

For the MWTF Project, ICF KH Quality Engineering has determined that the performance of an independent peer review will satisfy the requirements for independent design verification provided the reviewers are on the ICF KH Qualifications List maintained by the Chief Design Engineer, and that they have received the required training. In addition, the reviewers must use the Design Verification methodology (i.e., answer the 9 questions) and documentation process contained in ICF KH Procedure ES-7. 


\subsection{Checking}

Checking is an independent review of an unapproved document or drawing by a qualified individual. Checking of engineering documents is required by DOE Order 5700.6C (ref 14), NQA-1 Supplement 3S-1, and ICF KH Engineering Process Procedure ENG-2.3 (ref 15). The checker determines that all information is correct, complete, and consistent, and that all data is accurate. The checking function includes verification that the criteria used, sources, references, correspondence, standards, applicability of calculation methods, and existing conditions are correct. This activity may be called design verification for Safety Class 2, 3, and 4 systems and components. ICF KH Engineering Process Procedure ENG-2.3 thoroughly addresses the checking process for engineering documents. The experience and qualifications of a checker may not be at the level of a person performing peer review or formal design verification. Therefore, the checking activity is typically in addition to the independent peer review and/or design verification activities. However, on nonsafety class items and design deliverables, checking is considered the only design verification activity required in accordance with current WHC and ICF KH design process procedures.

\subsection{Conclusions}

Following are the conclusions related to the Project $\mathrm{W}-236 \mathrm{~A}$ peer review evaluation:

- A peer review is required for the W-236A project seismic, thermal and other selected design activities.

- The definition of a peer review contained in ASCE Manual No. 73 is the most applicable to the project.

- A peer review of the project seismic, thermal, and other selected design activities would be the equivalent of an ICF KH formal design verification.

- Since a project formal design verification of the seismic, thermal and other selected design activities must be accomplished, and since the ICF KH Technical Data Checklist can be used to assign design verification 


\section{H2SOA-T2-PP42}

responsibilities, a peer review could readily be substituted for the ICF KH formal design verification of seismic, thermal and other selected design activities.

- Both a peer review and a separate ICF KH formal design verification of these activities are not necessary, provided the peer review documentation follows the requirements of ICF KH Procedure ES-7.

- For nonsafety class designs, design verification (checking) will be accomplished in accordance with established WHC and/or ICF KH procedures, as applicable.

\subsection{Recommendations}

In cooperation with WHC counterparts, the ICF KH project team has prepared a Peer Review Analysis Matrix spreadsheet (Table 1) which identifies those items that will require formal peer review. The table notes recommended peer reviewing organizations as well as those items where continuous peer review would be advisable. Design verification, budget, and Professional Engineering (PE) stamping requirements are also listed. The budget column indicates by item which organization (i.e., WHC or ICF KH) has budgetary responsibility for the peer review activity. Not shown in this table are items that require independent seismic review only. These items are addressed in the MWTF Project Design Verification Plan, W236A-T2-AP12 (ref 16).

ICF KH believes that it would be advantageous to begin the peer review activity as early as possible and perform it concurrently with the associated design activity. This should help avoid the frequent "significant schedule impact" comments which are very common when the peer review is conducted at the end of the design process. Table 1 notes those items where continuous peer review is recommended. Additionally, items where the peer reviewing organization should possess an NQA-1 Quality Assurance (QA) program qualified to Supplement 3S-1 are identified. ICF KH Quality Engineering has determined that ICF KH affiliate organizations (i.e., ICF Kaiser Engineers) can . qualify under the ICF KH QA program provided that DOE approval is obtained. 
WHC-SD-W236A-TI-014

Rev.0

14236A-72-PPY2

Finally, an MWTF project Department Process Instruction (DPI) which covers the performance of independent peer reviews has been prepared (ref 17). The peer reviewers will be required to use this DPI in performing and documenting their individual peer review activities. 
WHC-SD-W236A-TI-014

Rev.0

W2SOA-12-PP12

\subsection{References}

1. W236A-PP2, Position Paper, "Peer Review of Selected Activities," MultiFunction Waste Tank Facility, prepared by ICF Kaiser Hanford Company, February, 1994.

2. DOE Order 6430.1A, "General Design Criteria," April 1989.

3. LBL-9143-83, "A Facsimile Report, Seismic Safety Guide," prepared by Lawrence Berkeley Laboratory, September 1983.

4. UCRL 15910, "Design and Evaluation Guidelines for DOE Facilities Subjected to Natural Phenomena Hazards," June 1990.

5. TM-5-809-10, "Joint Services Technical Manual, Seismic Design for Buildings," February 1982.

6. DOE-STD-1020-94, "Natural Phenomena Hazards Design and Evaluation Criteria for DOE Facilities," April 1994.

7. ASCE Manuals and Reports on Engineering Practice No. 73, "Quality in the Constructed Project," Volume 1, First Edition, 1988 revised.

8. ASME NQA-3, "Quality Assurance Program Requirements for the Collection of Scientific and Technical Information for Site Characterization of High-Level Nuclear Waste Repositories," 1989 Edition.

9. RHO-BW-MA-17, "Project Management Procedures Manual," Basalt Waste 'Isolation Project, Rev. 3, October 1987. 
10. WHC-SD-W236A-QAPP-001, "MWTF Quality Assurance Program Plan," Rev. 1, February 1994.

11. ASME NQA-1, "Quality Assurance Program Requirements for Nuclear Facilities," 1989.

12. WHC-CM-6-1, EP-4.1, "Standard Engineering Practices, Design Verification Requirements," prepared by Westinghouse Hanford Company, Rev. 4, June 1991.

13. ICF KH Procedure ES-7," Design Verification," Rev. 3, July 1991.

14. DOE Order 5700.6C, "Quality Assurance," October 1991.

15. ICF KH Engineering Process Procedure ENG-2.3, "Checking Design Documents," Rev. 0, March 1994.

16. W236A-T2-AP12, "Design Verification Plan," Multi-Function Waste Tank Facility, prepared by ICF Kaiser Hanford Company, August 1994.

17. 236A-DPI-4, Project W-236A Department Process Instruction, "Peer Review," Rev. 0, October 1993. 
Table 1. Independent Peer Review Analysis Matrix

\begin{tabular}{|c|c|c|c|c|c|c|c|c|}
\hline \multirow[t]{2}{*}{ sc } & \multirow[t]{2}{*}{ Item } & \multirow{2}{*}{$\begin{array}{c}\text { ICF KH } \\
\text { DV }\end{array}$} & \multirow{2}{*}{$\begin{array}{c}\text { WHC } \\
\text { DV }\end{array}$} & \multicolumn{4}{|c|}{ Final Peer Review } & \multirow{2}{*}{$\begin{array}{c}\text { PE Stamp } \\
\text { YIN }\end{array}$} \\
\hline & & & & By (Proposed): & Budget & $\begin{array}{l}\text { Qual. } \\
\text { Supp. }\end{array}$ & Contin. $^{8}$ & \\
\hline $1 / 2$ & WHC-SD-W236A-ER-004, Synthesis Document & $\mathbf{N}$ & $Y^{1}$ & EQE & WHC & N/A & $\mathrm{N}$ & $\mathbf{N}$ \\
\hline $1 / 2$ & WHC-SD-W236A-DGS-001, How-To Document & $\mathbf{N}$ & $Y^{\prime}$ & EQE & WHC & N/A & $\mathbf{N}$ & $\mathbf{N}$ \\
\hline $1 / 2$ & WHC-SD-GN-DGS-30008, Design Loads & $\mathbf{N}$ & $Y^{1}$ & N/A & $\mathrm{N} / \mathrm{A}$ & N/A & $\mathrm{N}$ & $\mathbf{N}$ \\
\hline 1 & Codes \& Standards Document (WHC) & $\mathrm{N}$ & $Y^{1}$ & S. Bush & WHC & N/A & $\mathrm{N}$ & $\mathbf{N}$ \\
\hline 1 & Code Selection Study (ICF KH) ER5 & $Y^{1}$ & $\mathrm{~N}$ & N/A & N/A & N/A & $\mathbf{N}$ & $\mathbf{N}$ \\
\hline $1 / 2$ & Soil-Structure Interaction (SSI) Analysis & $Y^{1,2}$ & $\mathrm{~N}$ & ICF KENallenas & ICF KH & $Y$ & $Y$ & Y \\
\hline $1 / 2$ & Thermal/Heat Transfer Analysis (WHC) & $\mathrm{N}$ & $Y^{1,2}$ & ICF KE/Julien & ICF KH & Y & Y & N \\
\hline $1 / 2$ & Thermal/Creep Analysis & $Y^{1,2}$ & $\mathbf{N}$ & ICF KENallenas & ICF KH & Y & Y & Y \\
\hline $1 / 2$ & Component Analysis & $Y^{1,2}$ & $\mathrm{~N}$ & ICF KENallenas & ICF KH & $Y$ & Y & Y \\
\hline $1 / 2$ & Primary \& Secondary Tank Analysis & $Y^{1.2}$ & $\mathbf{N}$ & ICF KENallenas & ICF KH & Y & Y & Y \\
\hline 1 & Insulating/Supporting Pad Study & $Y^{1}$ & $\mathrm{~N}$ & N/A & N/A & N/A & $\mathrm{N}$ & N \\
\hline 2 & $\begin{array}{l}\text { Misc. Studies (Tank-Tank, Slosh } \\
\text { Impact, Hyd. Effects, etc.) }\end{array}$ & $Y^{1,2}$ & $N$ & ICF KENVallenas & ICF KH & $Y$ & Y & $\mathrm{N}$ \\
\hline 2 & 200E/200W Geotechnical Statements of Work & $Y^{1}$ & $\mathrm{~N}$ & N/A & N/A & N/A & N & Y \\
\hline 2 & Soils Reports-200E \& $200 \mathrm{~W}^{3}$ & $Y^{1,2}$ & $\mathbf{N}$ & ICF KE/Becker & ICF KH & $Y$ & Y & $Y^{3}$ \\
\hline 1 & Tank Certified Design Specification & $Y^{1.2}$ & $\mathrm{~N}$ & RLCACloud & N/A & Y & $\mathrm{N}$ & $\mathrm{Y}^{4}$ \\
\hline 1 & Tank ASME Design Report (Fabricator) & Y & $\mathbf{N}$ & N/A & N/A & N/A & N & $Y^{5}$ \\
\hline 1 & Hazards Assessment (WHC/Geomatrix) & $\mathbf{N}$ & $Y^{1}$ & EQE/Golder & WHC & N/A & $\mathrm{N}$ & $N$ \\
\hline 2 & Support Facility Seismic & $Y^{1.2}$ & $\mathbf{N}$ & ICF KENallenas & ICF KH & Y & $\mathbf{N}$ & Y \\
\hline 2 & Process Piping Seismic & $Y^{1,2}$ & $\mathbf{N}$ & ICF KENalkenas & ICF KH & $Y$ & $\mathbf{N}$ & Y \\
\hline 2 & Vent System Seismic & $Y^{1,2}$ & $\mathrm{~N}$ & ICF KENallenas & ICF KH & $Y$ & $\mathbf{N}$ & $Y$ \\
\hline
\end{tabular}

${ }^{1}$ Internal check/review

${ }^{2}$ Peer Review by Qualified Supplier to be substituted for Design Verification

${ }^{3}$ By Shannon \& Wilson
${ }^{4}$ By R. Reedy

${ }^{5}$ By Constructor

DDefinition - see text 